\title{
SQUAMANITA ODORATA (AGARICALES, BASIDIOMYCOTA), NEW MYCOPARASITIC FUNGUS FOR POLAND
}

\author{
MareK Halama
}

\begin{abstract}
The rare and interesting fungus Squamanita odorata (Cool) Imbach, a parasite on Hebeloma species, is reported for the first time from Poland, briefly described and illustrated based on Polish specimens. Its taxonomy, ecology and distribution are discussed.
\end{abstract}

Key words: Coolia, distribution, fungicolous fungi, mycoparasites, Poland, Squamanita

Marek Halama, Museum of Natural History, Wrocław University, Sienkiewicza 21, 50-335 Wrocław, Poland; e-mail: marek.halama@uwr.edu.pl

\section{INTRODUCTION}

The genus Squamanita Imbach is one of the most enigmatic genera of the known fungi. All described species of the genus probably are biotrophs that parasitize and take over the basidiomata of other agaricoid fungi, including Amanita Pers., Cystoderma Fayod, Galerina Earle, Hebeloma (Fr.) P. Kumm., Inocybe (Fr.) Fr., Kuehneromyces Singer \& A.H. Sm., Phaeolepiota Konrad \& Maubl. and possibly Mycena (Pers.) Roussel. As a result the host is completely suppressed or only more or less recognizable, and the Squamanita basidioma is a fusion or chimera of its tissues and those of its host (Redhead et al. 1994; Bas \& Læssøe 1999; Kibby 2009; Matheny \& Griffith 2010; Bunyard 2011). Species of Squamanita are extremely rare and sporadic all over the world, and finding a Squamanita can be quite an adventure (Henrici 2005; Cervini et al. 2009; Matheny \& Griffith 2010). The genus comprises at least twelve known species at present (Redhead et al. 1994; Bas \& Thoen 1998; Bas \& Læssøe 1999; Kirk et al. 2008), seven of which have been found in Europe (Redhead et al. 1994; Ludwig 2001). These numbers probably reflect the level of knowledge in Europe as compared to the rest of the world rather than the true picture of the distribution of Squamanita species.

In Poland only one species of the genus Squamanita has been recorded previously. Squama- nita paradoxa (Smith \& Singer) Bas, a parasite on Cystoderma, was reported by Z. Domański from one locality in the Lasy Łochowskie forest near Wyszków (valley of the Lower Bug River, E Poland) in September 1973 (Domański 1997; cf. Wojewoda 2003). This collection was made in a young forest of Pinus sylvestris L., where $S$. paradoxa was found growing on the ground, among grass, on the edge of the forest. Recently, another species, Squamanita odorata (Cool) Imbach, was found in northern Poland (Fig. 1). It is reported here as new for the country.

\section{MATERIAL AND METHODS}

The description of basidioma morphology and ecological notes are based on original material. The macroscopic features were studied from fresh material of one collection comprising several basidiomata in different stages of development. Microcharacters were observed with a Nikon Eclipse E-400 light microscope fitted with a Nikon DS-Fil digital camera. All microscopic structures were observed from dried material. Freehand sections of rehydrated pieces of basidiomata were examined in $5 \% \mathrm{NH}_{3} \cdot \mathrm{H}_{2} \mathrm{O}$ reagent with $1 \%$ Phloxine $\mathrm{B}$. Image-grabbing and biometric analyses were done with NIS-Elements D 3.1 imaging software. Dimensions of microcharacters are given as (minimum) average \pm standard deviation (maximum), 
and additionally as main data range (10-90 percentile values). The $Q$ value is the length/width ratio of basidiospores. For basidiospores, randomly selected mature spores were measured without the hilar appendix. The length of basidia was measured excluding sterigmata. Statistical computations employed Statistica (StatSoft). Morphological terminology follows Vellinga (1988) and Bas (1965). The studied collections are deposited in the Museum of Natural History, Wrocław University, Wrocław, Poland (WRSL).

\section{RESULTS AND DISCUSSION}

Squamanita odorata (Cool) Imbach

Fig. 2

Mitt. naturf. Ges. Luzern 15: 83. 1946 - Lepiota odorata Cool, Medded. Nedl. Mycol. Ver. 9: 47-52. 1918 Coolia odorata (Cool) Huijsman, Medded. Nedl. Mycol. Ver. 28: 60. 1943 - Tricholoma odoratum (Cool) Konrad \& Maubl., Encyclop. Mycol. 14: 436. 1949.

Illustrations (selected): Kops et al. (1924: plate 2039a), Pearson (1952: plate 3, fig. 2), Bas (1965: 343, figs. 11-20), Stuntz and Isaacs (1967: 286, fig. 39), Læssøe (1985: 67, fig. 3), Gueny and Chiaffi (1994: 22, figs 1-8; 24, figs 1-6), Breitenbach and Kränzlin (1995: 223, fig. \& photo 261), Ludwig (2000: 174, plate 172, fig. 81.4), Sutter and Klarer (2000: 60-63), Ludwig (2001: 657), Kasparek (2002: 68-69, photos), Roux (2006: 483), Leach (2013: 53, fig. 1, 54, fig. 3, back cover).

Basidiomata springing from tuber-like, galled tissue, forming clusters of 2-4 basidiomata (the association with Hebeloma mesophaeum was not observed). Pileus 5-20 mm, initially hemispherical, then convex to low-convex, not hygrophanous, dry, radially fibrillose, covered with slightly pointed, darker and flat or recurved scales (especially at margin) and flat obtuse-angular felted patches (especially in center), greyish violet to dark violet. Lamellae rather distant, $\mathrm{L}=20-30$, $1=1-2$, broadly adnate, slightly paler than pileus, pale greyish violet, rather thick, with concolorous, entire edge. Stipe $8-15 \times 2.0-3.5 \mathrm{~mm}$, cylindrical or slightly widening below, dry, concolorous with pileus, minutely loosely longitudinally fibrillose, with 2-4 incomplete belts of more or less erect and recurved floccose-fibrillose, dark violaceous grey-brown scales (especially at base). Amorphous

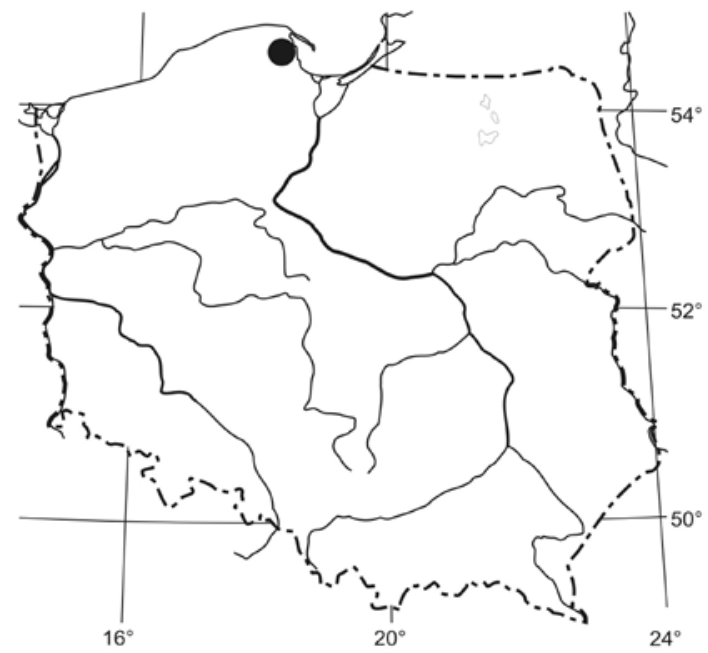

Fig. 1. Known distribution of Squamanita odorata (Cool) Imbach in Poland.

gall (transformed host tissue), 10-20 mm diam., pale brownish yellow. Context pale dingy violaceous to whitish in pileus and stipe, ochraceous buff in gall. Smell of basidioma fruity to nauseous (unpleasant). Taste not verified. Spore deposit not obtained.

Basidiospores (5.5-) $6.8 \pm 0.5(-8.3) \times(4.1-)$ $5.1 \pm 0.4(-6.2) \mu \mathrm{m}, 6.1-7.4 \times 4.6-5.5 \mu \mathrm{m}, \mathrm{Q}=(1.1-)$ $1.3 \pm 0.1(-1.6), \mathrm{Q}=1.2-1.4(\mathrm{n}=161)$, ellipsoid, broadly ellipsoid to ovoid, rarely obovoid and subreniform, thin-walled, colorless to slightly dingy in ammonia, smooth, with small hilar appendix, not reacting with Melzer's solution. Basidia (23.8-) $33.7 \pm 4.2(-40.9) \times(5.7-) 7.5 \pm 0.7(-8.9) \mu \mathrm{m}$, $28.5-39.0 \times 6.5-8.2 \mu \mathrm{m}(\mathrm{n}=48)$, narrowly clavate, in majority $4-$ spored, but also with 2-3 sterigmata. Cheilocystidia and pleurocystidia not observed. Chlamydospores of irregular shape (7.6-) $11.4 \pm 2.1(-18.9) \times(3.9-) 5.2 \pm 0.6(-6.6) \mu \mathrm{m}$, $8.9-13.7 \times 4.5-6.0 \mu \mathrm{m}(\mathrm{n}=118)$, arthrosporic or at times aleurosporic, produced by clamped hyphae, thin-walled to moderately thickened, colorless to yellowish in ammonia, smooth, not reacting with Melzer's solution, formed within an abortive host tissue. Pileipellis a trichoderm grading to a cutis, consisting of 6-16 $\mu \mathrm{m}$ wide and 25-55 $\mu \mathrm{m}$ long, violaceous grey to brownish grey hyphae. Pigment parietal and in places minutely encrusting. 

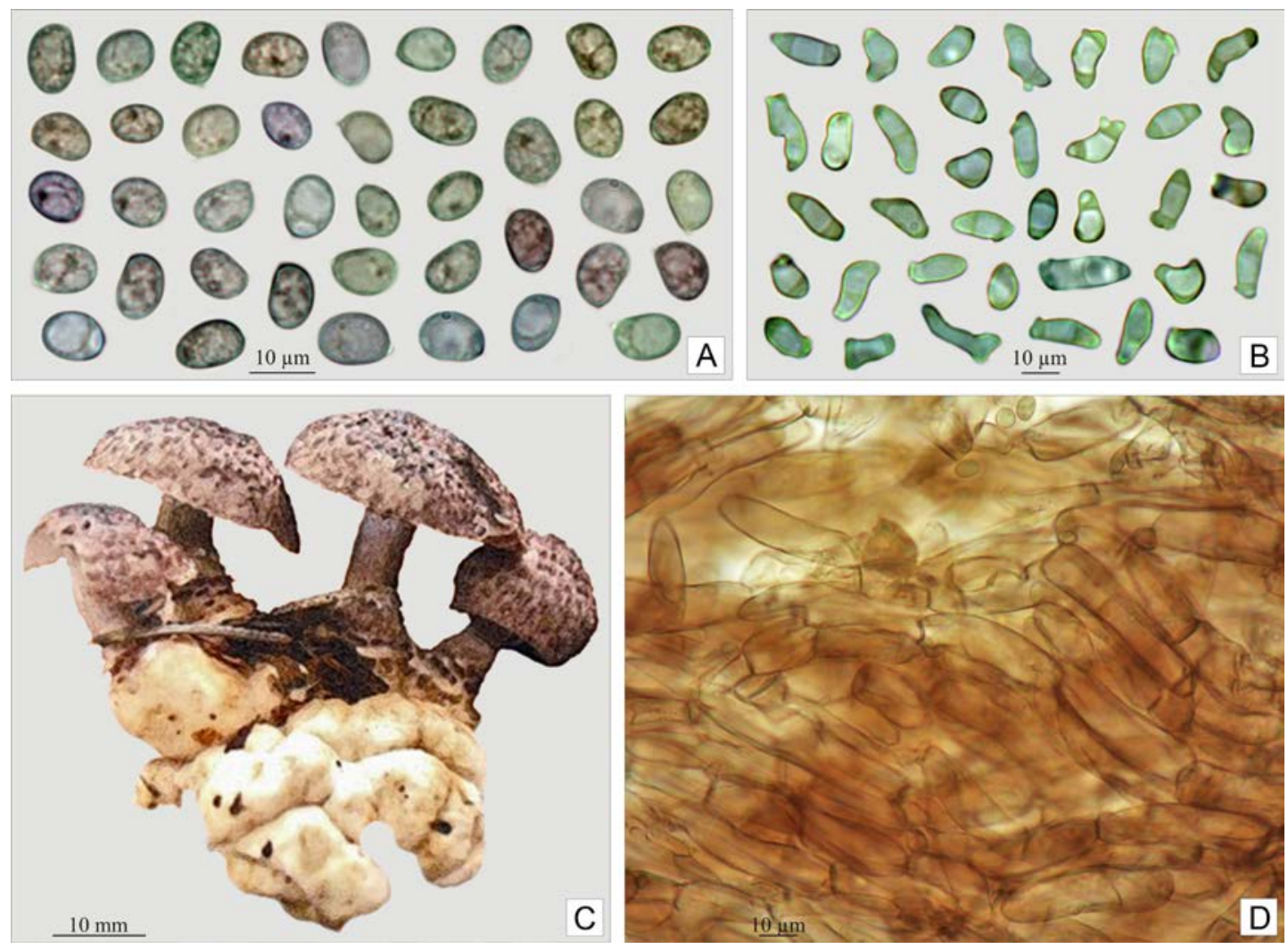

Fig. 2. Squamanita odorata (Cool) Imbach. A - basidiospores, B - chlamydospores, C - side view of basidiomata (photo courtesy of E. Fałtynowicz), D - hyphae of pileipellis (all from WRSL EF-2009-0001).

Clamp-connections abundant in pileipellis (also observed at base of basidia).

SPECIMENS EXAmined: POLAND, Kashubian LAKE DisTRICT: Zbychowo, Narcyzowa Street 11, sandy soil - among scattered coniferous litter, allotment with scattered Pinus sylvestris trees, alt. $132 \mathrm{~m}, 54^{\circ} 33^{\prime} 31^{\prime \prime} \mathrm{N}$, $18^{\circ} 18^{\prime} 41^{\prime \prime} \mathrm{E}, 13$ Oct. 2009, leg. E. Faltynowicz (WRSL EF-2009-0001).

The macro- and microscopic features of the collected specimens of Squamanita odorata are characteristic of the species. Parameters such as basidioma size and color, basidiospore measurements and shape, and the remaining microcharacters match well the description and iconography of $S$. odorata given by other authors (e.g., Cool 1918; Bas 1965; Gueny \& Chiaffi 1994; Breitenbach \& Kränzlin 1995). However, the specimens from Poland differ slightly in chlamydospore size from other well-described ones. Both Bas (1965) in his description based on rich material (including type material) and Wasser (1993) describe somewhat smaller conidia $(9-13 \times 4.5-6.0 \mu \mathrm{m}, 7-13 \times$ $4.0-6.5 \mu \mathrm{m})$. These differences are not significant and probably should be considered within the variability of the species. Chlamydospores of $S$. odorata are formed by the mycelium in tuber-like, galled tissue ('protocarpic tuber', 'cecidiocarp') provoked by infection of the host basidiomata, and according to Redhead et al. (1994) are a developmental characteristic presumably to be noted as the transformed host ages or decays. This may be why chlamydospores were not reported by a number of authors in their collections (Münzmay 1990; Breitenbach \& Kränzlin 1995; Sutter \& Klarer 2000; Kasparek 2002). Bas (1965) and Redhead et al. (1994) reported the presence of 'dingy' basidiospores among more abundant hyaline ones 
in $S$. odorata. This feature was also confirmed by observations on the basidiospores from the Polish collection of the species.

The most recent key to European species of Squamanita was published by Henrici (2013). A microscopic study does not seem to be needed to recognize $S$. odorata within the limits of the genus. This species is very well characterized by its strong and heavy, sweetish aromatic (aromaticfruity) odor, recalling that of Hebeloma sacchariolens Quél., and by the conspicuous, ochraceous tuber-like gall from which comparatively small, short-stipitate, scaly and more or less violaceous basidiomata arise (often more than one from each tuber). Squamanita paradoxa and S. pearsonii Bas produce similar basidiomata, but they differ by the absence of a tuber-like gall (basidiomata springing from only somewhat inflated galled host tissue and usually singly) and their not so distinctive odor. In addition, both $S$. pearsonii and $S$. paradoxa produce dextrinoid basidiospores, though sometimes very weakly (Læssøe 2012; Henrici 2013).

Squamanita odorata grows on the strongly deformed and unrecognizable basidiomata of its host. The Polish collection is consistent with this characteristic as well. An unusual feature of the majority of recent Danish collections of $S$. odorata is that they were accompanied by Hebeloma mesophaeum (Pers.: Fr.) Quél (Vesterholt 1991). That circumstance (not recorded at the location in Zbychowo), together with the distinct raphanoid smell and taste of the basal bulb of the $S$. odorata, supported the reasonable suspicion of a parasitic relationship with this species (Vesterholt 1991). Suggestions of the possible biotrophic status of other Squamanita species were published even earlier (Reid 1983; Harmaja 1988; Nagasawa et al. 1990). Molecular studies by Mondiet et al. (2007) finally confirmed the prior suspicion and revealed $H$. mesophaeum as host of $S$. odorata. According to Henrici (2013), future collections on other Hebeloma species remain a possibility for this fungus.

Squamanita odorata occurs in a variety of habitats, including coniferous and broadleaved woodland, forest plantations, and wooded areas with mossy patches, sand dunes and urban spaces (parks, gardens), just as the presumed host occurs. The Polish site of $S$. odorata seems to confirm that this fungus is found mainly in anthropogenically disturbed and ruderal environments; an important share of its records are from sites along paved roads or paths on disturbed soil (e.g., Bas 1965, 1966; Daams 1966; Mondiet et al. 2007; SennIrlet et al. 2007; Læssøe 2012; Henrici 2013). The habitat preferences of $S$. odorata seem easy to explain: H. mesophaeum is well adapted to successional or disturbed environments, so the parasite is found at similar sites.

In Europe $S$. odorata has ca 60 known locations in Belgium, Denmark, Finland, France, Germany, Italy, Norway, Sweden, Switzerland and the Netherlands (e.g., Cool 1918; Lange 1953; Bas 1965, 1966; Daams 1966; Gulden et al. 1977; Glowinski \& Gumbinger 1982; de Vries 1985; Læssøe 1985, 2012; Münzmay 1990; Krieglsteiner 1991; Vesterholt 1991; Chrispijn \& Douwes 1993; Gueny \& Chiaffi 1994; Stridvall \& Stridvall 1994; Wanningen 1995; Walleyn 1998; Watling \& Turnbull 1998; Sutter \& Klarer 2000; Arnolds \& Keizer 2001; Kasparek 2004; Onofri 2005; Walleyn et al. 2006; Courtecuisse \& Duhem 2007; Senn-Irlet et al. 2007; Siepe \& Kasparek 2009; Brandrud et al. 2010; Glaser 2010; Henrici 2013; Leach 2013; Kytöharju 2015). The finding in Poland extends the known distribution of the species to Eastern Europe. Most likely S. odorata is more widespread on the continent than records indicate. According to Wasser (1993), this species is expected to grow also in the Baltic States, CIS States and Ukraine (cf. Vishnevskiy 1998). Outside Europe $S$. odorata has been found in western North America (Stuntz \& Isaacs 1967; Arora 1986; Redhead et al. 1994).

Squamanita odorata is considered threatened in several countries. It is on the red list of fungi in Denmark under category NT (near threatened), in Germany under category R (rarity; of latent threat), in Norway under category VU (vulnerable), in Switzerland under category CR (critically endangered), and in the Netherlands as endangered (BE) (Benkert et al. 1992; Senn-Irlet et al. 2007; Arnolds \& Veerkamp 2008; Brandrud et al. 2010; Anonymous 2012). 
ACKNOwledgements. I am grateful to Elżbieta Fałtynowicz for providing her collection and photos of Squamanita odorata and for her advisory note on its habitat, Bernadeta Pawlik (Cracow, Poland) and Mario Cervini (Castononno, Italy) for their kind help with mycological literature, and the anonymous reviewers for helpful remarks and suggestions on the manuscript. The study was funded by the Museum of Natural History, University of Wrocław.

\section{REFERENCES}

Anonymous 2012. The Danish Red Data Book. [July 2012]. http://www.dmu.dk/en/animalsplants/red_data_book/.

Arnolds E. \& KeIzer P. J. 2001. Netherlands field study week in Het Woold. Coolia 44(2): 69-91.

Arnolds E. \& Veerkamp M. 2008. Basisrapport Rode Lijst Paddenstoelen. Nederlandse Mycologische Vereniging, Utrecht.

Arora D. 1986. Mushrooms Demystified. 2 ed. Ten Speed Press, Berkeley, California.

Bas C. 1965. The genus Squamanita. Persoonia 3(3): 331-359.

BAs C. 1966. Squamanita odorata II. Coolia 12(3-5): 14-17.

Bas C. \& LÆssøe T. 1999. Squamanita granulifera sp. nov. A first record of Squamanita (Agaricales) from South America. Kew Bull. 54(3): 811-815.

BAS C. \& ThOEN D. 1998. Squamanita citricolor, a new species from Central Africa. Persoonia 17(1): 135-139.

Benkert D., Dörfelt H., Hardtke H.-J., Hirsch G., KreiSel H., Krieglsteiner G. J., LÜDeritz M., Runge A., Schmid H., Schmitt J. A., Winterhoff W., WöldeCKe K., Zehfuss H.-D., Einhellinger A., Gross G., Grosse-Brauckmann H., Nuss I. \& Wölfel G. 1992. Rote Liste der gefährdeten Großpilze in Deutschland. Deutsche Gesellschaft für Mykologie e.V. \& Naturschutzbund Deutschland e.V. (NABU), IHW-Verlag, Eching.

Brandrud T. E., Bendiksen E., Hofton T. H., Høiland K. \& Jordal J. B. 2010. Sopp (Fungi). In: J. A. KÅLÅs, Å. Viken, S. Henriksen \& S. SkJelseth (eds), The 2010 Norwegian Red List for Species, pp. 87-123. Artsdatabanken, Trondheim.

BreitenbaCh J. \& KränZlin F. 1995. Fungi of Switzerland. 4. Agarics ( $2^{\text {nd }}$ Part). Verlag Mykologia, Luzern.

Bunyard B. A. 2011. The paradoxical Squamanita, a mycoparasitic symbiont. Fungi 4(5): $28 \& 42$.

Cervini M., Gulden G. \& Bendiksen E. 2009. A second find of the mycoparasitic agaric Squamanita fimbriata, and a note on conservation of its locus classicus. Agarica 28: 6-13.

ChrisPiJn R. \& Douwes R. 1993. De achterhoek binnenlandse werkweek 1992. Coolia 36(3): 87-94.
Cool C. 1918. Lepiota odorata n. sp. Med. Ned. Mycol. Ver. 9: $47-52$.

Courtecuisse R. \& Duhem B. 2007. Guide des champignons de France et d'Europe. Delachaux et Niestlé, Paris.

DAAMs J. 1966. Squamanita odorata I. Coolia 12(3-5): 14.

DE VRIES G. A. 1985. Squamanita odorata en Geastrum pectinatum, twee zeldzame fungi in de bossen tussen Baarn en Hilversum. Coolia 28(3): 53-55.

DOMAŃSKI Z. 1997. Nowe stanowiska rzadkich i interesujących grzybów w Polsce. Author-publisher, Warszawa.

GLASER T. 2010. Squamanita odorata, der Duftende Schuppenwulstling, ein bemerkenswerter Pilzfund 'vor der Haustür'. Mycol. Bavar. 11: 29-35.

Glowinski H. \& Gumbinger M. 1982. Drei seltene und z.T. neue Makromyzeten aus der BRD: Cystoderma simulatum, Stropharia ochrocyanea, Squamanita odorata. Z. Mykol. 48(1): 35-40.

GuenY M. \& ChiAfFi M. 1994. Squamanita odorata (Cool) Imbach ex Bas, premiere recolte signalee en France. Bull. Soc. Mycol. France 110(1): 17-27.

Gulden G., Bendiksen E. \& Brandrud T. E. 1977. A new agaric, Squamanita fimbriata sp. nov., and a first find of S. odorata in Norway. Norweg. J. Bot. 24(3): 155-158.

Harmaja H. 1988. Studies on the agaric genera Singerocybe n.gen. and Squamanita. Karstenia 27: 71-75.

Henrici A. 2005. Notes and records. Field Mycol. 6(2): 71-72.

Henrici A. 2013. Squamanita in Britain and Europe. Field Mycol. 14(2): 56-63.

KASPAReK F. 2002. Porträt Nr. 45: Duftender Schuppenwulstling. Tintling 7(1): 68-69.

KaspareK F. 2004. Tintling-Dialog mit Fredi Kasparek. Tintling 9(1): $38-47$.

KIBBy G. 2009. Editorial. Field Mycol. 10(1): 2.

Kirk P. M., Cannon P. F., Minter D. V. \& Stalpers J. A. 2008. Ainsworth \& Bisby's Dictionary of Fungi. $10^{\text {th }} \mathrm{ed}$. $\mathrm{CAB}$ International, Wallingford.

Kops J., van Eeden F. W. \& Vuyck L. (eds) 1924. Flora Batava. 26. Martinus Nijhoff, 's Gravenhage.

Krieglsteiner G. J. 1991. Verbreitungsatlas der Großpilze Deutschlands (West). 1. Ständerpilze. Teil B: Blätterpilze. Part II. Eugen Ulmer GmbH i Co., Stuttgart.

KYtöHarJu S. 2015. Natural Fungi in Finland. [15 June 2015]. http://www.velutipes.com/natural/index.htm.

LæSSøE T. 1985. Nyt fund af Vellugtende Knoldfod (Squamanita odorata (Cool) Bas) i Danmark. Svampe 12: 66-67.

LÆSSøE T. 2012. Squamanita Imbach. In: H. KNUdSEN \& J. VeSTERHOlt (eds), Funga Nordica. Agaricoid, Boletoid, Clavarioid, Cyphelloid and Gastroid Genera, pp. 657-659. Nordsvamp, Copenhagen. 
LANGe M. 1953. Coolia odorata (Cool) Huijsman f. bispora f. nov. found in Denmark. Friesia 4(4-5): 307-309.

LeaCH J. 2013. Squamanita odorata found in Britain. Field Mycol. 14(2): 53-55.

Ludwig E. 2000. Pilzkompendium. 1: Abbildungen. IHW-Verlag, Eching.

LudwIG E. 2001. Pilzkompendium. 1: Beschreibungen. IHW-Verlag, Eching.

Matheny P. B. \& Griffith G.W. 2010. Mycoparasitism between Squamanita paradoxa and Cystoderma amianthinum (Cystodermateae, Agaricales). Mycoscience 51(6): 456-461.

Mondiet N., Dubois M.-P. \& Selosse M.-A. 2007. The enigmatic Squamanita odorata (Agaricales, Basidiomycota) is parasitic on Hebeloma mesophaeum. Mycol. Res. 111(5): 599-602.

MünZMAY T. 1990. Seltene Agaricales vom Niederrhein. Mitteilungsblatt der Arbeitsgemeinschaft Pilzkunde Niederrhein $(A P N)$ 8(1): 26-33.

Nagasawa E., Hongo T. \& NARITA D. 1990. Squamanita odorata (Agaricales) from Japan. Rep. Tottori Mycol. Inst. 28: 135-141.

ONOFri S. (ed.) 2005. Checklist dei funghi italiani. Basidiomycetes. Carlo Delfino, Sassari.

Pearson A. A. 1952. New records and observations. V. T. Brit. Mycol. Soc. 35(2): 97-122.

Redhead S. A., Ammirati G. R., Walker G. R., Norvell L. L. \& Puccio M. B. 1994. Squamanita contortipes, the Rosetta Stone of a mycoparasitic agaric genus. Canad. J. Bot. 72(12): 1812-1824.

REID D. A. 1983. A second British collection of Squamanita paradoxa. Bull. Brit. Mycol. Soc. 17(2): 111-113.

Roux P. 2006. Mille et un champignons. Édition Roux, SainteSigolène.

SenN-Irlet B., Bieri G. \& EgLi S. 2007. Rote Liste der gefährdeten Grosspilze der Schweiz. Umwelt-Vollzug Nr. 0718. Bundesamt für Umwelt BAFU und der Eidgenössischen Forschungsanstalt für Wald, Schnee und Landschaft WSL, Bern, Birmensdorf.

SiePe K. \& KaspareK F. 2009. Die Großpilze (Eumycota, Macromycetes) des Truppenübungsplatzes Haltern-Borkenberge (Kreise Coesfeld und Recklinghausen). Abh. Westfäl. Mus. Naturk. 71(3): 117-134.
Stridvall L. \& Stridvall A. 1994. Släktet Squamanita Imbach i Sverige. Jordstjärnan 15(1): 24-37.

Stuntz D. E. \& Isaacs B. F. 1967. Pacific northwestern fungi. I. Mycologia 54(3): 272-298.

Sutter R. \& Klarer J. 2000. Der Pilz des Monats (4): Squamanita odorata mit Nachtrag von B. Kobler. Schweiz. Z. Pilzk. 78(2): 58-62.

Vellinga E. C. 1988. Glossary. In: C. Bas, T. W. Kuyper, M. E. Noordeloos \& E. C. Vellinga (eds), Flora Agaricina Neerlandica. 1: 54-64. A. A. Balkema Publishers, Rotterdam.

Vesterholt J. 1991. Vellugtende Knoldfod - måske en parasit. Svampe 24: 11.

VishneVSKIY M. V. 1998. Trikholomovye griby (Tricholomatales) Moskvy i Moskovskoy oblasti: sistematika, flora, ekologiya. Izdatel'stvo Dom „Muravey”, Moskva.

Walleyn R. 1998. Twee zeldzame Agaricales gevonden in België. Sterbeeckia 18: 11-12.

Walleyn R., Antonissen I., de HaAn A., de HaAn M., De Keyser J., Hendrickx H., Lachapelle J., Le Jeune G., Mervielde H., Noten L., Schoutteten J., van de KercKhove O., van de Put K., Verbeken A., Volders J., Lenaerts L., Monnens J., Termonia W., Van der Veken P., Van Ryckegem G., Vandeven É., Beker H., Bogaerts A., De Kesel A., De Pauw S., Dielen F., Ghyselinck D., Hanssens C. \& VANNIEUWERBURGH L. 2006. Standaardlijst van Basidiomycota en Myxomycota van Vlaanderen en het Brussels Gewest. In: R. WALLEYN \& É. VANDEVEN (eds), Standaardlijst van Basidiomycota en Myxomycota van Vlaanderen en het Brussels Gewest. Rapport INBO.R.2006.27, pp. 1-143 + errata. Instituut voor Natuur- en Bosonderzoek, Brussel.

WANnINGen D. 1995. Beginners geluk. Coolia 38(3): 105-106.

WASSER S. P. 1993. Tribes Cystodermateae Sing. and Leucocoprineae Sing. of the CIS and Baltic States. IHW-Verlag, Eching.

Watling R. \& Turnbull E. 1998. Cantharellaceae, Gomphaceae and amyloid-spored and xeruloid members of Tricholomataceae (excl. Mycena). In: D. M. Henderson, P. D. Orton \& R. Watling (eds), British fungus flora agarics and boleti. 8: 43-47. Royal Botanic Garden, Edinburgh.

Wojewoda W. 2003. Checklist of Polish larger Basidiomycetes. Biodiversity of Poland. 7. W. Szafer Institute of Botany, Polish Academy of Sciences, Kraków. 